\title{
Impact of adding natural bioactive mixture composed of lemon, onion, and garlic juice at different levels on productive performance, egg quality, and some blood parameters of commercial laying hens
}

Hamed A. A. Omer', Gamal M. H. El-Mallah', Soha S. Abdel-Magid", Neamat I. Bassuony², Sawsan M. Ahmed ${ }^{1}$ and Abdel Khalek A. El-Ghamry'

\begin{abstract}
Background: The World Health Organization (WHO) encourages using medicinal herbs and plants to substitute or minimize the use of chemicals through the global trend to go back to nature. Many studies mentioned that using medicinal herbs and plants as feed additives seems to be a recent trend depending on availability and their cost but using them with monogastric animals and birds, as pharmaceutical tool, is available. Their action was manifested in a reduced expanding range of pathogenic microorganisms in the digestive tract, which resulted in the improvement of growth performance, efficient digestion, immunity, and health of poultry.

Methods: The present work aimed to establish the influence of adding natural bioactive mixture composed of the juice of lemon, onion, and garlic (LOG) at portions 1.00, 1.00, and 0.125/I clean water, respectively, to laying hens' diets on their performance, egg quality, and some blood constituents. Seventy-two 30-week-old commercial Bovan Brown layers were randomly divided into four dietary treatment groups. Each treatment included eighteen hens in 6 replicates (3 birds each). All tested diets were almost isocaloric and isonitrogenous.

Results: Adding LOG in laying hens' diets significantly $(P<0.05)$ improved feed conversion throughout the second stage of egg collection in comparison with the control group. Inclusion of LOG in laying hen diets significantly $(P<0.05)$ improved the number of eggs/hen, percentage of egg production, and egg mass/hen throughout the second stage of egg collection comparing with the control $\left(\mathrm{G}_{1}\right)$. Diet supplied by $1 \%$ LOG recorded the best value of yolk color (5.40) and yolk percentage (28.42\%) compared with the other groups. Adding $2 \%$ or $3 \%$ LOG significantly $(P<0.05)$ decreased the total plasma cholesterol content compared to the control group. Inclusion of LOG at different levels significantly $(P<0.05)$ decreased blood plasma contents of GPT and GOT. However, insignificant decreases in blood plasma creatinine occurred comparing to control.

Conclusion: Adding the natural bioactive mixture composed of the juice of lemon, onion, and garlic can be safely used in improving the general health, egg weight, and feed conversion with decreasing the blood cholesterol of laying hens. Supplementation of LOG in the ration of hens improved the feed conversion and egg production.
\end{abstract}

Keywords: Laying hens, Natural bioactive mixture, Performance, Egg quality, Blood plasma constituents

\footnotetext{
* Correspondence: Soha_Syd@yahoo.com

${ }^{1}$ Animal Production Department, National Research Centre, 33 El-Bohouth

Street, Dokki, P.O: 12622, Giza, Cairo, Egypt

Full list of author information is available at the end of the article
} 


\section{Introduction}

Egg is an important animal protein resource which is greater than other protein resources in terms of amino acid score and is a rich source of minerals, vitamins, and other nutrients; moreover, lower price of egg has caused all segments of society to be able to access this highquality protein resource. Anyways, quality and quantity of produced egg highly depend on nutritional and health management of laying hen farms (Motamedi and Taklimi 2014).

In general, using medicinal herbs and plants with humans has been known since the old civilizations. Old drug industry depended upon the raw material of medicinal herbs and plants and their extracts, which proved safe. Inversely, many synthesized chemicals' additives caused many hazards to animal, plants, and humans. The World Health Organization (WHO) encourages using medicinal herbs and plants to substitute or minimize the use of chemicals through the global trend to go back to nature (El-Ashry et al. 2006).

Feed additive as garlic, onion, and lemon juice is experiencing a resurgence in animal health and production too. Meanwhile, the risk of the presence of human health has led to its prohibition for use in animal antibiotic, residues in milk and meat, and its effects on feeds (Wagr et al. 1994).

Dietary factors play a key role in the development of various human diseases, including cardiovascular disease. Garlic and its preparations have been widely recognized as agents for prevention and treatment of cardiovascular and other metabolic diseases, atherosclerosis, hyperlipidemia, thrombosis, hypertension, and diabetes (Banerjee and Maulik 2002).

The key active ingredient in garlic is a powerful plant chemical called allicin which rapidly decomposes to several volatile organosulfur compounds with bioactivities (Chang and Cheong 2008). Garlic (Allium sativum, Chihabi's Dictionary of Agricultural and Allied Terminology 1988) is used both as condiment and medicament, anticoagulant, antioxidant, hypolipidaemic, antihypertensive, antiaging, antiplatelet, and heavy metal detoxifier (Agarwal 1996; Marilynn 2001).

Lemon (Citrus limonum, Chihabi's Dictionary of Agricultural and Allied Terminology 1988) is a good source of potassium (145 mg/100 g fruit); calcium (61 mg); vitamin $C$ (40 to $50 \mathrm{mg} / 100 \mathrm{~g}$ ); vitamins $\mathrm{A}, \mathrm{B}_{1}, \mathrm{~B}_{2}$, and $\mathrm{B}_{3}$; and $27 \mathrm{Kcal} / 100 \mathrm{~g}$ (Murray 1993; Chevallier 1996). Also, lemon includes volatile oil (2.5\% of the peel), limonene, alpha-terpinene, alpha-pinene, citral, coumarins, mucilage, pectins, and bioflavonoids (mostly from pith and peel as noted by Chevallier (1996), Miyake et al. (1999), Fisher and Phillips (2006), Manners (2007), and Miyake et al. (2007)). Lemon juice and lemon oil have been evaluated for antimicrobial action. The oil shows some bacteriostatic and antiviral action thought to be due to citral and linalool content (Fisher and Phillips 2006; Manners 2007). In addition for that, lemon also contained some active antioxidant compounds such as flavonoids, isoflavones, flavones, anthocyanins, coumarins, lignans, catechins, and isocatechins as reported by (Prior 2003; Ibrahim et al. 2011). Antimicrobial compounds produced by microorganisms have long been used in animal diets as growth promoters (Barragry and Powers 1994). However, their use has become highly regulated due to the possible development of drug resistance in human pathogenic bacteria (CAFA 1997).

Garlic (Allium sativum) has been used as spice and folk medicine since antiquity (Rivlin 2001). Bioactive components of garlic, including several sulfur-containing compounds such as alliin, diallyl sulfides, and allicin, may partly account for some effects of garlic (Amagase et al. 2001). These components are known to possess antibacterial (Sivam 2001), antifungal, antiparasitic, antiviral (Ankri and Mirelman 1999), antioxidant (Prasad et al. 1995), antithrombotic, vasodilatory, and anticancer (Agarwal 1996) activities.

Onion (Allium cepa L.) bulbs possess numerous organic sulphur compounds including Trans-S-(1-propenyl) cysteine sulfoxide, $S$-methyl-cysteine sulfoxide, spropylcycteine sulfoxides and cycloallicin, flavinoids, phenolic acids, sterols including cholesterol, stigma sterol, b-sitosterol, saponins, sugars and a trace of volatile oil compounds mainly of sulphur compounds. Also, most of the plant parts contain compounds with proven antibacterial, antiviral, antiparasitic, and antifungal properties and have antihypertensive, hypoglycemic, antithrombotic, antihyperlipidemic, anti inflammatory and antioxidant activity (Lampe 1999, Melvin et al. 2009). Both garlic and onion have been shown to have applications as antimicrobial, antithrombotic, antitumor, hypolipidaemic, antiarthritic, and hypoglycemic agents. In recent years, extensive research has focused on the beneficial and medicinal properties of garlic and onions. In particular, the use of these agents in the treatment and prevention of cardiovascular disease and cancer is an area of considerable investigation and interest (Ali et al. 2000; Williams and Lamprecht 2008).

Many investigators reported that garlic and onion are highly inhibitory to Escherichia coli and to other bacteria and fungi, e.g., antibacterial and antifungal (Sato et al. 1990), as enzyme inhibitory (Kumar and Berwal 1999).

Activities of garlic and onion have been widely studied; the active inhibitory principle of garlic is allicin or daily thiosolphinic acid (Saleem and Al-Delaimy 1982). Allicin is enzymatically released from precursor form when the garlic and onion bulbs are crushed.

Garlic, onion, and lemon juice is highly inhibitory to molds and fungi (Elgyyar et al. 2001). Also, Wangensteen 
et al. (2004), Khir and Ibrahim Nany (2007), Aiad et al. (2008), and Ahmed et al. (2009) noted that adding natural additive to feed well increases the antioxidant content and may have potentials as a natural antioxidant and thus inhibit unwanted oxidation processes.

So, this study aimed to establish the influence of incorporation natural bioactive mixture composed of the juice of lemon, onion, and garlic (LOG) at different levels on performance, egg quality, and some blood plasma constituents of commercial Bovan Brown laying hens.

\section{Methods}

This study was carried out at El-Nubaria Experimental and Production Station at El-Imam Malik Village which belongs to the Animal Production Department, National Research Centre, 33 El-Bohouth Street, Dokki, Cairo, Egypt.

This work was carried out in cooperation work between Animal Production Department, National Research Centre and Regional Centre for Food and Feed, Agriculture Research Centre, Ministry of Agriculture, Giza, Egypt.

\section{Preparation the natural mixture for Feed supplementary}

It is composed of the juice of lemon, onion, and garlic (LOG) at portions $1.00,1.00$, and $0.125 / 1$ clean water, respectively, of which its addition to laying hens' diets influenced their performance, egg quality, and some blood constituents.

\section{Animal experiment design}

Seventy-two 30-week-old commercial Bovan Brown layers were housed in individual wire cages and divided into four equal treatment groups of thirty hens each (10 replicates of three birds each). All hens were kept under the same managerial, hygienic, and environmental temperature which ranged from 22 to $38^{\circ} \mathrm{C}$ and humidity from 40 to $60 \%$ during over all the experimental intervals (3 periods of 4 weeks each). Also, the lighting schedule was 16 -h light to 8 -h dark/day.

The experimental diets consisted of antibiotic-free layer mash formulated to meet the nutrient requirement for layers as established by NRC (1994).

Feed and water were offered ad libitum. Egg weight (EW) and egg number (EN) were recorded daily. Feed intake (FI) was recorded weekly, while feed conversion ratios (FCR) were calculated.

\section{Egg quality assessment}

Six eggs from each treatment were used after being weighed. Using a Vernier Caliper, egg shape index was assessed by measuring the egg length (along the longitudinal axis) and egg width (along the equatorial axis). The index was expressed as a ratio of width to length according to the following equation as extrapolated by Anderson et al. (2004).

$$
\text { Shape index }=\text { egg width } \times 100 / \text { egg length }
$$

Each egg was then carefully broken onto a flat plate, and the height of the albumen was measured midway between the yolk and the edge of albumen using a tripod micrometer. The yolk was separated from the albumen and weighed, and the albumen Haugh units were calculated from the tables according to the relationship between egg weight and albumen high as described by Doyon et al. (1986) depending on the following equation:

$$
\mathrm{HU}=100 \log \left(\mathrm{H}-1.7 \mathrm{~W}^{0.37}+7.6\right)
$$

where $\mathrm{HU}=$ Haugh unit, $H=$ height of the albumen (millimeters), and $W=$ weight of the egg (grams).

Also, yolk index was estimated according to the relationship between yolk high and yolk diameter using the following equation:

$$
\text { Yolk index }=\text { yolk high } \times 100 / \text { yolk diameter }
$$

Shell thickness of the dried shells with intact membrane was measured with a micrometer (Lasec, Berlin, Germany) to the nearest $0.01 \mathrm{~mm}$ and calculated as the mean of 3 measurements taken at the broad end, equator, and narrow end as noted by Günlü et al. (2003).

Albumen weights were obtained by determining the difference between the whole egg weight and weights of yolk and shell added together.

Ingredient used in diet formulations is presented in Table 1; meanwhile, compositions of different experimental diets and calculations of control diet are shown in Table 2.

\section{Analytical procedures}

Chemical analysis of feed ingredients was analyzed according to AOAC (2005) methods.

At the end of the third stage of egg collection, blood samples were collected from the wing vein of laying hens using sterilized syringes and needles. Collection of blood samples were centrifuged at $4000 \mathrm{rpm}$ for $20 \mathrm{~min}$, for preparation of blood plasma. Plasma was kept frozen at $-18^{\circ} \mathrm{C}$ for subsequent analysis.

Various blood plasma chemical parameters were calorimetrically determined using commercial kits, following the same steps as described by the manufacturers.

Plasma total protein was determined according to Armstrong and Carr (1964) and Witt and Trendelenburg (1982) and albumin according to Doumas et al. (1971) 
Table 1 Chemical analysis (\%) of feed ingredients

\begin{tabular}{lllll}
\hline Item & Soybean meal (SBM) & Protein concentrations & LOG & Yellow corn (YC) \\
\hline Moisture & 6.39 & 3.05 & 96.73 & 7.35 \\
Chemical analysis on DM basis & & & & \\
$\quad$ Organic matter (OM) & 94.84 & 92.72 & 2.93 & 98.61 \\
Crude protein (CP) & 44.00 & 45.00 & 1.90 & 9.22 \\
Crude fiber (CF) & 4.41 & 2.96 & 0.00 & 4.07 \\
Ether extract (EE) & 0.77 & 1.49 & 1.03 & 4.51 \\
$\quad$ Nitrogen-free extract (NFE) & 45.66 & 43.27 & 0.00 & 80.81 \\
Ash & 5.16 & 7.28 & 0.34 & 1.39 \\
$\quad$ Metabolizable energy (kcal/kg DM) & 3152 & 3129 & 139 & 3038 \\
\hline
\end{tabular}

*Metabolizable energy (kcal/kg DM) was calculated according to NRC (1994)

LOG natural bioactive mixture juice composed of lemon, onion, and garlic juice at portions $1.00,1.00$, and $0.125 / \mathrm{l}$ clean water

and (Tietz 1986); globulin was calculated by subtracting the albumin value from the total protein value and total cholesterol according to Allain et al. (1974) and Pisani et al. (1995). Alkaline phosphates activity was measured according to the method of Beliefield and Goldberg (1971); plasma glutamic oxaloacetic transaminase (GOT) and glutamic pyruvic transaminase (GPT) activities were determined as described by Reitman and Frankel (1957) and Harold (1975); creatinine (Husdan 1968); high- density lipoprotein (HDL) concentration was estimated according to the Assmann (1979). Also, albumin to globulin ratio (A:G ratio) was calculated.

\section{Statistical analysis}

Data collected for laying hens' performance including the number of egg/hen, egg production percentages, egg mass, egg weight, feed consumption, and feed conversion; blood parameters including total protein, albumin,

Table 2 Composition and calculated chemical analysis of the experimental diets

\begin{tabular}{|c|c|c|c|c|}
\hline \multirow[t]{2}{*}{ Ingredients } & \multicolumn{4}{|c|}{ Experimental diets } \\
\hline & Control, $\mathrm{D}_{1}$ & $1 \%$ LOG, $\mathrm{D}_{2}$ & $2 \% L_{L}, D_{3}$ & $3 \%$ LOG, $D_{4}$ \\
\hline \multicolumn{5}{|l|}{ Composition of experimental diets } \\
\hline Yellow corn & 64.00 & & & \\
\hline Soybean meal & 23.50 & \multirow{7}{*}{$\begin{array}{l}\text { Control diet } \\
+10 \mathrm{ml} \\
\text { LOG } \\
\text { per } \\
\text { kg feed }\end{array}$} & \multirow{7}{*}{$\begin{array}{l}\text { Control diet } \\
+20 \mathrm{ml} \\
\text { LOG } \\
\text { per } \\
\mathrm{kg} \text { feed }\end{array}$} & \multirow{7}{*}{$\begin{array}{l}\text { Control diet } \\
+30 \mathrm{ml} \\
\text { LOG } \\
\text { per } \\
\text { kg feed }\end{array}$} \\
\hline Protein concentrates & 3.00 & & & \\
\hline Dicalcium phosphate & 1.50 & & & \\
\hline Limestone & 7.50 & & & \\
\hline Methionine & 0.05 & & & \\
\hline Mineral and vitamin premix* & 0.20 & & & \\
\hline Sodium chloride & 0.25 & & & \\
\hline \multicolumn{5}{|c|}{ Calculated chemical analysis of control diet } \\
\hline Moisture & 6.49 & 6.55 & 6.62 & 6.68 \\
\hline \multicolumn{5}{|l|}{ Chemical analysis on dry matter basis } \\
\hline Organic matter (OM) & 88.44 & 88.44 & 88.43 & 88.43 \\
\hline Crude protein (CP) & 17.64 & 17.66 & 17.68 & 17.70 \\
\hline Crude fiber (CF) & 3.73 & 3.72 & 3.71 & 3.70 \\
\hline Ether extract (EE) & 3.11 & 3.12 & 3.13 & 3.14 \\
\hline Nitrogen free extract (NFE) & 63.96 & 63.94 & 63.91 & 63.89 \\
\hline Ash & 11.56 & 11.56 & 11.57 & 11.57 \\
\hline Metabolizable energy (kcal/kg DM) & 2779 & 2780 & 2782 & 2783 \\
\hline
\end{tabular}

Metabolizable energy (kcal/kg DM) was calculated according to NRC (1994)

LOG natural bioactive mixture juice composed of lemon, onion and garlic juice at portions $1.00,1.00$, and $0.125 / \mathrm{I}$ clean water

*Ingredients per kg diet: Mg, 56 mg; Fe, 20 mg; Cu, 10 mg; Zn, 50 mg; Co, 125 mg; l, 0.8 mg, vitamin A, 10,000 IU; vitamin D3, 2000 IU; vitamin E, 5 IU; vitamin K, 2

$\mathrm{mg}$; riboflavin, $4.20 \mathrm{mg}$; vitamin B12, $0.01 \mathrm{mg}$; pantothenic acid, $5 \mathrm{mg}$; nicotinic acid, $20 \mathrm{mg}$; folic acid, $0.5 \mathrm{mg}$; choline, $3 \mathrm{mg}$ 
globulin, A:G ratio, total cholesterol, HDL, GPT, GOT, alkaline phosphates, and creatinine; and egg quality including egg weight, shape index, yolk index, Haugh unit, yolk color, shell thickness, albumin percentage, yolk percentage, and shell percentage were subjected to statistical analysis using the one way analysis of variance according to SPSS (2008). Duncan's multiple range test (Duncan 1955) was used to separate means when the dietary treatment effect was significant according to the following model:

$$
\mathrm{Yij}=\mu+\mathrm{Ti}+\mathrm{eij}
$$

where $\mathrm{Y}_{\mathrm{ij}}=$ observation; $\mu$ =overall mean; $\mathrm{T}_{i}=$ effect of experimental diets for $i=1-4,1=$ laying hens receiving diet not containing LOG, 2 = laying hens receiving diet sprayed by $10 \mathrm{ml} \mathrm{LOG} / \mathrm{kg}$ feed, 3 = laying hens receiving diet sprayed by $20 \mathrm{ml} \mathrm{LOG} / \mathrm{kg}$ feed, and $4=$ laying hens receiving diet sprayed by $30 \mathrm{ml}$ LOG/ $\mathrm{kg}$ feed; and $\mathrm{e}_{\mathrm{ij}}=$ the experimental error.

\section{Results}

\section{Composition and calculated chemical analysis of} experimental diets

Data presented in Table 2 show that control diet was formulated to cover the laying hens' diets $(17 \% \mathrm{CP}$ and $2750 \mathrm{kcal} \mathrm{ME} / \mathrm{kg} \mathrm{DM}$ feed). Chemical analyses of different tested diets approximately were not altered by LOG compared with control diet. So, all tested diets appear almost isocaloric and isonitrogenous.

\section{Performance of laying hens}

Data illustrated in (Table 3) clear that adding LOG had no significant effect on average of egg weight throughout the three stages of egg collection. In the first stage, $G_{4}$ is superior $(P<0.05)$ compared to $\mathrm{G}_{3}$. However, it had no significant effect on feed consumption/hen/day throughout the first and second stages of egg collection. On the other hand, feed conversion insignificantly improved through out of the first and third stages of egg collection, but it was significantly $(P<0.05)$ improved through out of second stage of egg collection in comparison with the control group hens.

\section{Egg production of laying hens}

Data presented in Table 3 clear that adding LOG in laying hens' diets significantly $(P<0.05)$ improved the number of eggs/hen, percentage of egg production, and egg mass/hen throughout the second stage of egg collection comparing with the control. Egg production and quality are heritable traits of major concern for breeders and consumers. To improve these characteristics, correct nutritional, management, and environmental practices are needed to enhance egg production and

Table 3 Performance of laying hens receiving different dietary treatments

\begin{tabular}{|c|c|c|c|c|c|c|}
\hline Item & $\begin{array}{l}\text { Number of } \\
\text { egg/hen }\end{array}$ & $\begin{array}{l}\text { Percentage of } \\
\text { egg production }\end{array}$ & $\begin{array}{l}\text { Egg } \\
\text { mass/hen (g) }\end{array}$ & $\begin{array}{l}\text { Average of egg } \\
\text { weight }(\mathrm{g})\end{array}$ & $\begin{array}{l}\text { Feed consumption } \\
\text { /hen/day }\end{array}$ & $\begin{array}{l}\text { Feed } \\
\text { conversion }\end{array}$ \\
\hline \multicolumn{7}{|l|}{ First period (28 days) } \\
\hline Control $\left(G_{1}\right)$ & 22.20 & 79.29 & 1265.07 & $56.94^{\mathrm{ab}}$ & 119.71 & 2.63 \\
\hline $1 \% \operatorname{LOG}\left(G_{2}\right)$ & 22.77 & 81.31 & 1328.88 & $58.32^{\mathrm{ab}}$ & 126.35 & 2.61 \\
\hline $2 \% \operatorname{LOG}\left(\mathrm{G}_{3}\right)$ & 22.92 & 81.84 & 1288.44 & $56.20^{b}$ & 122.13 & 2.67 \\
\hline $3 \% \operatorname{LOG}\left(G_{4}\right)$ & 22.92 & 81.84 & 1352.42 & $59.04^{\mathrm{a}}$ & 117.81 & 2.44 \\
\hline Overall mean \pm SE & $22.70 \pm 0.22$ & $81.07 \pm 0.78$ & $1308.70 \pm 15.70$ & $57.63 \pm 0.32$ & $121.50 \pm 1.20$ & $2.59 \pm 0.04$ \\
\hline \multicolumn{7}{|c|}{ Second period (28 days) } \\
\hline Control $\left(G_{1}\right)$ & $22.86^{\mathrm{b}}$ & $75.60^{b}$ & $1326.21^{\mathrm{b}}$ & 58.01 & 128.44 & $2.72^{\mathrm{a}}$ \\
\hline $1 \% \operatorname{LOG}\left(\mathrm{G}_{2}\right)$ & $24.90^{\mathrm{a}}$ & $82.34^{\mathrm{a}}$ & $1489.48^{\mathrm{a}}$ & 59.86 & 121.21 & $2.29^{b}$ \\
\hline $2 \% \operatorname{LOG}\left(\mathrm{G}_{3}\right)$ & $25.05^{\mathrm{a}}$ & $82.84^{\mathrm{a}}$ & $1463.08^{\mathrm{a}}$ & 58.37 & 126.29 & $2.42^{\mathrm{b}}$ \\
\hline $3 \% \operatorname{LOG}\left(G_{4}\right)$ & $24.48^{\mathrm{ab}}$ & $80.95^{\mathrm{ab}}$ & $1449.27^{a}$ & 59.18 & 122.74 & $2.37^{b}$ \\
\hline Overall mean \pm SE & $24.32 \pm 0.24$ & $80.43 \pm 0.78$ & $1432.01 \pm 15.44$ & $58.86 \pm 0.30$ & $124.67 \pm 1.02$ & $2.45 \pm 0.03$ \\
\hline \multicolumn{7}{|l|}{ Third period (28 days) } \\
\hline Control $\left(G_{1}\right)$ & 21.84 & 72.22 & 1278.72 & 58.55 & $124.26^{\mathrm{ab}}$ & 2.73 \\
\hline $1 \% \operatorname{LOG}\left(G_{2}\right)$ & 23.01 & 76.09 & 1399.71 & 60.79 & $129.96^{\mathrm{a}}$ & 2.61 \\
\hline $2 \% \operatorname{LOG}\left(\mathrm{G}_{3}\right)$ & 22.95 & 75.89 & 1362.69 & 59.25 & $122.59^{\mathrm{ab}}$ & 2.54 \\
\hline $3 \% \operatorname{LOG}\left(G_{4}\right)$ & 23.01 & 76.09 & 1411.48 & 61.23 & $121.69^{b}$ & 2.43 \\
\hline Overall mean \pm SE & $22.70 \pm 0.22$ & $75.07 \pm 0.70$ & $1363.15 \pm 19.04$ & $59.96 \pm 0.53$ & $124.63 \pm 0.96$ & $2.58 \pm 0.04$ \\
\hline
\end{tabular}

a, beans in the same column having different superscripts differ significantly $(P<0.05)$

SEM standard error of mean, LOG natural bioactive mixture juice composed of lemon, onion, and garlic juice at portions $1.00,1.00$, and $0.125 / /$ clean water 
quality. Eggs are delicate product which can lose quality rapidly during the period of collection to consumption.

\section{Egg quality of laying hens}

Data presented in Table 4 clear that incorporation LOG at different levels of supplementation in laying hens' diets had no significant effect on all parameters of egg quality; however, insignificant increases were noticed with egg weight, shape index, yolk index, and shell thickness in comparison with the control group. On the other hand, laying hens receiving 1\% LOG-containing diet recorded the best value of yolk color (5.40) and yolk $\%(28.42 \%)$ compared with the other groups.

Moreover, Haugh unit insignificantly decreased with adding LOG in laying hens' diets. Meanwhile, laying hens offered 2\% LOG recorded the highest value of shell percentage (12.84) in comparison with the other groups.

\section{Blood plasma constituents of laying hens}

Data illustrated in Table 5 show that incorporation of $1 \%$ LOG in laying hens' diets $\left(\mathrm{G}_{2}\right)$ insignificantly increased both total protein and globulin in comparison with the control; meanwhile, the others of two levels of supplementation $\left(\mathrm{G}_{3}\right.$ and $\left.\mathrm{G}_{4}\right)$ significantly $(P<0.05)$ decreased the total protein and globulin comparing with control and 1\% LOG. On the other hand, $\mathrm{G}_{2}$ significantly $(P<0.05)$ increased the albumin content; however, $G_{3}$ and $G_{4}$ insignificantly increased the content of albumin compared to control. Moreover, A:G ratio significantly $(P<0.05)$ increased by adding 2 or 3\% LOG (G3 and G4) compared to control.

\section{Lipid content}

Data of lipid contents including both HDL and total cholesterol (Table 5) cleared that incorporation of LOG in laying hen diets at $1 \%$ or $3 \%$ insignificantly decreased HDL content; meanwhile, laying hens receiving $2 \%$ LOG-containing diet caused a significant $(P<0.05)$ decrease in their content of plasma LDL. Incorporation of $2 \%$ or $3 \%$ LOG caused a significantly $(P<0.05)$ decrease in the total plasma cholesterol content compared to control and 1\% LOG-containing diets.

\section{Liver function}

Inclusion of LOG at different levels significantly $(P<0.05)$ decreased blood plasma contents of GPT and GOT in laying hens (Table 5).

\section{Kidney function}

Adding LOG at different levels insignificantly decreased blood plasma content of creatinine compared to control (Table 5). On the other hand, incorporation of LOG at $2 \%$ or $3 \%$ significantly $(P<0.05)$ decreased alkaline phosphatase.

\section{Discussion}

The present results of chemical analysis (Table 2) were formulated to cover the laying hens' diets (17\% CP and $2750 \mathrm{kcal} \mathrm{ME} / \mathrm{kg}$ DM feed) as reported by (NRC 1994).

The present results of feed intake were in agreement with those noticed by Khan et al. (2008) who noted that supplementation of garlic powder had no effect on the feed consumption in native Desi laying hens. Also, Qureshi et al. (1983b) did not report any differences in daily feed consumption of pullets fed diets with various garlic products at levels equal to about $50 \mathrm{~kg} /$ ton of added garlic bulb. On the other hand, Khan et al. (2007), Nusairat (2007), and Asrat et al. (2018) reported that feed consumption of layers was increased with increasing the level of garlic powder supplementation in laying diets. This is an attribute of rich aromatic oil content of garlic which enhances digestion. Also, Adibmoradi et al. (2006) observed that garlic administration enhanced villus height and crypt depth and decreased epithelial thickness and goblet cell numbers in the duodenum, jejunum, and ileum of birds. The morphological changes

Table 4 Egg quality of laying hens fed with different dietary treatments

\begin{tabular}{|c|c|c|c|c|c|}
\hline \multirow[t]{2}{*}{ Item } & \multicolumn{4}{|c|}{ Experimental groups } & \multirow{2}{*}{$\begin{array}{l}\text { Overall } \\
\text { mean } \pm \text { SE }\end{array}$} \\
\hline & Control $\left(G_{1}\right)$ & $1 \% \operatorname{LOG}\left(\mathrm{G}_{2}\right)$ & $2 \% \operatorname{LOG}\left(G_{3}\right)$ & $3 \% \operatorname{LOG}\left(G_{4}\right)$ & \\
\hline Egg weight & 55.40 & 60.20 & 57.40 & 59.80 & $58.20 \pm 0.97$ \\
\hline Shape index & 75.44 & 76.40 & 77.62 & 77.83 & $76.82 \pm 0.29$ \\
\hline Yolk index & 43.30 & 46.03 & 44.87 & 43.77 & $44.49 \pm 0.48$ \\
\hline Haugh unit & 86.80 & 82.00 & 83.60 & 82.60 & $83.75 \pm 0.81$ \\
\hline Yolk color & 5.20 & 5.40 & 5.00 & 5.20 & $5.20 \pm 0.08$ \\
\hline Shell thickness & 28.80 & 33.00 & 34.60 & 29.40 & $31.45 \pm 1.16$ \\
\hline Albumin $\%^{1}$ & 62.72 & 60.54 & 61.64 & 63.50 & $62.10 \pm 0.58$ \\
\hline Yolk \% ${ }^{1}$ & 26.10 & 28.42 & 25.51 & 25.05 & $26.27 \pm 0.42$ \\
\hline Shell \% ${ }^{1}$ & 11.18 & 11.04 & 12.84 & 11.44 & $11.63 \pm 0.34$ \\
\hline
\end{tabular}

LOG natural bioactive mixture juice composed of lemon, onion and garlic juice at portions 1.00, 1.00, and 0.125/l clean water; SEM standard error of mean

${ }^{1}$ Percentage of egg weight 
Table 5 Blood plasma constituents of laying hens fed with different dietary treatments

\begin{tabular}{|c|c|c|c|c|c|}
\hline \multirow[t]{2}{*}{ Item } & \multicolumn{4}{|c|}{ Experimental groups } & \multirow{2}{*}{$\begin{array}{l}\text { Overall } \\
\text { mean } \pm \text { SE }\end{array}$} \\
\hline & Control $\left(G_{1}\right)$ & $1 \% \operatorname{LOG}\left(\mathrm{G}_{2}\right)$ & $2 \% \operatorname{LOG}\left(G_{3}\right)$ & $3 \% \operatorname{LOG}\left(\mathrm{G}_{4}\right)$ & \\
\hline Total protein, g/dl & $7.35^{\mathrm{a}}$ & $7.80^{\mathrm{a}}$ & $6.20^{\mathrm{b}}$ & $6.60^{\mathrm{b}}$ & $6.99 \pm 0.20$ \\
\hline Albumin, g/dl & $2.45^{\mathrm{b}}$ & $2.95^{\mathrm{a}}$ & $2.55^{\mathrm{ab}}$ & $2.60^{\mathrm{ab}}$ & $2.64 \pm 0.08$ \\
\hline Globulin, g/dl & $4.90^{\mathrm{a}}$ & $4.85^{\mathrm{a}}$ & $3.65^{\mathrm{b}}$ & $4.00^{b}$ & $4.35 \pm 0.18$ \\
\hline A:G ratio & $0.50^{\mathrm{b}}$ & $0.61^{\mathrm{ab}}$ & $0.70^{\mathrm{a}}$ & $0.65^{\mathrm{a}}$ & $0.62 \pm 0.03$ \\
\hline $\mathrm{HDL}, \mathrm{mg} / \mathrm{dl}$ & $16.65^{\mathrm{a}}$ & $12.10^{\mathrm{ab}}$ & $7.10^{\mathrm{b}}$ & $13.40^{\mathrm{a}}$ & $12.31 \pm 1.25$ \\
\hline Total cholesterol, mg/dl & $115.00^{\mathrm{a}}$ & $119.00^{\mathrm{a}}$ & $62.00^{\mathrm{b}}$ & $72.00^{b}$ & $92.00 \pm 8.29$ \\
\hline GPT, U/L & $82.00^{\mathrm{a}}$ & $39.00^{\mathrm{b}}$ & $59.00^{\mathrm{b}}$ & $42.00^{b}$ & $55.50 \pm 5.78$ \\
\hline GOT, U/L & $28.00^{\mathrm{a}}$ & $16.00^{\mathrm{b}}$ & $9.00^{c}$ & $14.00^{b}$ & $16.75 \pm 2.20$ \\
\hline Alkaline phosphates, U/L & $14.00^{\mathrm{a}}$ & $13.00^{\mathrm{ab}}$ & $12.00^{\mathrm{b}}$ & $8.00^{c}$ & $11.75 \pm 0.73$ \\
\hline Creatinine, mg/dl & 0.23 & 0.25 & 0.24 & 0.28 & $25.00 \pm 0.01$ \\
\hline
\end{tabular}

$\mathrm{a}, \mathrm{b}, \mathrm{c}$ Means in the same row having different superscripts differ significantly $(P<0.05)$

SEM standard error of mean, HDL high-density lipoprotein, GOT glutamic oxaloacetic transaminase, GPT glutamic pyruvic transaminase, LOG natural bioactive mixture juice composed of lemon, onion and garlic juice at portions 1.00, 1.00, and 0.125/I clean water

in the birds' gut proclaim improvement in the digestive capacity and improved activity of the pancreatic enzyme. Also, Chowdhury et al. (2002) showed that feed consumption and feed efficiency were not affected by supplementation of $0,2,4,6,8$, or $10 \%$ garlic paste $(P>0.05)$ as averaged over the 6 -week period. The discrepancy between the results of this experiment and other similar work might be resulted due to the fact that the duration of the experiment was different and also the difference in garlic products. The present results of feed conversion were in agreement with those attributed by Lewis and Elvin-Lewis (2003) and Demir et al. (2003) who concluded an improvement in the feed conversion ratio of broilers fed garlic. Meanwhile, Asrat et al. (2018) found that feed conversion was not affected by the addition of garlic powder in White Leghorn hens.

The improvement in egg quality (Table 3) is of paramount importance in the field of production and management (Mahmoud et al. 2010). There is a dearth of literature available concerning the beneficial effects of garlic or onion or their juices on egg quality. So, Yalcin et al. (2006) observed that egg weight increased when laying hens were fed 5 and $10 \mathrm{~g} / \mathrm{kg}$ garlic powder. Also, Khan et al. (2007) reported that egg production increased during the 6 weeks in which $0,2,6$, or $8 \%$ garlic powder was fed to laying hens. On the other hand, Canogullari et al. (2010) noted that egg production increased significantly by adding $1 \%$ garlic powder in the feed of laying hens. Meanwhile, Reddy et al. (1991) and Chowdhury et al. (2002) showed that the supplementation of garlic powder did not affect egg production. Moreover, Khan et al. (2012) found that garlic is one of such potential feed supplements which has recently been reported as having a wide range of beneficial effects of the production performance and physiological biochemistry of laying hens. However, Chowdhury et al. (2002) recorded that egg production was not affected by supplementation of $0,2,4,6,8$, or $10 \%$ garlic paste as averaged over the 6 -week period.

Egg quality of laying hens (Table 4) in agreement with those noted by Canogullari et al. (2010) who showed that egg weight, yolk index, shell weight, shell thickness, yolk weight did not change when laying hens were fed with diet containing $1 \%$ garlic powder; meanwhile, eggshell index and Haugh unit decreased significantly when laying hens received diet containing $4 \%$ garlic powder. Meanwhile, Yalcin et al. (2006) reported that the supplementation of garlic had no significant effect on egg albumin index, eggshell index, and egg Haugh unit values when laying hens were fed with diets containing 5 or $10 \mathrm{~g} / \mathrm{kg}$ garlic powder for 22 weeks. On the other hand, Mahmoud et al. (2010) recorded that egg albumin, yolk and shell weight, albumin height, and Haugh unit were improved when laying hens were supplemented with $0.25,0.50$, and $1 \%$ garlic juice. Moreover, Mottaghitalab and Taraz (2002) noted that the inclusion of $0,5,10$, and $15 \mathrm{~g} / \mathrm{kg}$ garlic powder significantly decreased yolk weight. But, Khan et al. (2008) showed that feeding $8 \%$ garlic powder may result in better egg production in Desi laying hens, with no effect on egg mass and egg weight. The differences in the results of different reports may be due to the different experiment protocols and garlic preparation in their experiments (Canogullari et al. 2010).

Blood plasma constituents of laying hens (Table 5) were exactly near from the results obtained by Elkatcha et al. (2016) who showed that garlic extract (allicin) supplementation at $50 \mathrm{mg} / \mathrm{kg}$ diet significantly increased total protein and albumin concentrations by about 4.7 and 5.9\%, respectively, while allicin 
supplementation at 25,75 , or $100 \mathrm{mg} / \mathrm{kg}$ had no significant effect on total protein and albumin concentrations compared with the control. Also, they noted that allicin supplementation had no significant effect on globulin blood serum concentration compared to the control. Moreover, Oleforuh-Okoleh et al. (2015) noted that the total protein, albumin, and globulin significantly increase with adding garlic compared with the control one. Also, the present results were in agreement with those noted by Omer et al. (2015) who indicated that the incorporation of LOG in growing rabbits at $0.5,1$, 1.5 , and $2 \%$ had no significant effect on total protein and globulin, while it significantly affected $(P<0.05)$ albumin for rabbit receiving 1 or $1.5 \%$ LOG and albumin to globulin ratio for rabbit offered with diet containing 1.5\% LOG. Also, Ahmed et al. (2009) reported that serum total protein was not significantly affected by the natural additive (LOG) when added to calves' rations. In addition, Bush (1991) noted a positive correlation between dietary protein and plasma protein concentration. This indicates that the supplement had not affected protein synthesis in liver function. Also, the low level of proteins may be attributed to a decrease in the protein absorbed and synthesized and an increase in protein losses. Also, Hassan and Abdel-Raheem (2013) mentioned that calves fed with diets containing garlic had greater $(P<0.05)$ serum concentrations of globulin.

Lipid content (Table 5) in harmony with those obtained by Motamedi and Taklimi (2014) noted that laying hens receiving diets containing $1 \%$ garlic powder, $1 \%$ fenugreek, and $1 \%$ garlic powder $+0.5 \%$ fenugreek decreased LDL compared to the control group. Also, Saffa (2007) reported a reduction in total concentration of plasma cholesterol as well as LDL as a result of adding garlic and fenugreek to the diet of laying hens. On the other hand, Motamedi and Taklimi (2014) observed that inclusion of $2 \%$ garlic and fenugreek had beneficial effects on the cholesterol metabolism without having any adverse effect on the laying hens' performance. In addition, Ao et al. (2010) studied the effect of using garlic powder on plasma cholesterol concentration of laying hens, and they noted that by increasing the amount of garlic powder in the diet from 0.00 to $3 \%$, blood serum cholesterol concentration has been significantly decreased. Meanwhile, Saki et al. (2014) observed that levels of serum HDL in laying hen fed with diets containing 8 or $12 \mathrm{~g} \mathrm{~kg}^{-1}$ herb mixture were increased significantly. Interestingly, LDL levels were increased by supplementation of phytogenic feed additive treatments. However, serum triglyceride and cholesterol concentration were not affected by herb mixture supplementation. Also, Canogullari et al. (2010) showed that plasma HDL and LDL levels were higher in birds fed with diets containing 10, 20, or $40 \mathrm{~g} \mathrm{~kg}^{-1}$ garlic powder than those in the control diet. On the other hand, Azeke and Ekpo (2009) noted that the reductions of the total cholesterol, total triglyceride, LDL, and HDL were observed by garlic powder supplementation at levels of 10 and $20 \mathrm{~g} \mathrm{~kg}^{-1}$ in laying hens' diet. Canogullari et al. (2010), Kim et al. (2009), and Chowdhury et al. (2002) have shown that plasma LDL cholesterol was dropped linearly with $5-20 \mathrm{~g} \mathrm{~kg}^{-1}$ garlic powder in diet, but HDL cholesterol concentration was not affected. Meanwhile, Ghasemi et al. (2010) reported that plasma levels of cholesterol, triglyceride, HDL, and LDL were not affected by dietary inclusion of 0.1 and $0.2 \mathrm{~g} \mathrm{~kg}^{-1}$ mixture of garlic and thyme powder. Meanwhile, Omer et al. (2015) noted that incorporation of LOG as natural bioactive mixture in rabbit rations at $1.5 \%$ or $2 \%$ significantly $(P<0.05)$ decreased total cholesterol in comparison with the control, while the addition of $0.5 \%$ or $1 \%$ LOG did not alter significantly with the other groups. Also, they reported that treatments contained (1\%, $1.5 \%$, and $2 \%$ LOG) significantly $(P<0.05)$ decreased low-density lipoprotein (LDL), while it had no significant effect on high-density lipoprotein (HDL) for rabbits. In addition, Hassan and AbdelRaheem (2013) found that calves fed with diets containing garlic caused lowering in cholesterol content compared to those fed with the control diet. Also, El-Ashry et al. (2006), Abo El-Nor et al. (2007), and Ahmed et al. (2009) observed that the mean values of blood metabolites were higher in animals fed with diets containing medicinal herbs than the control. The lowering in total cholesterol in the present study could be ascribed to LOG which is thought to have various pharmacologic properties. Lower serum and liver cholesterol (Qureshi et al. 1983a) inhibit bacterial growth (Cavallito and Bailey 1944), inhibit platelet growth, and reduce oxidative stress (Horie et al. 1992).

Results of liver function (Table 5) were in disagreement with those obtained by Ahmed et al. (2009) who found that blood components of GPT and GOT were significantly increased $(P<0.05)$ by increasing natural additive (LOG) in calves. On the other hand, Omer et al. (2015) noted that the incorporation of LOG in rabbit diets significantly $(P<0.05)$ decreased GOT; meanwhile, it had no significant effect on the GPT content. Also, Hassan and Abdel-Raheem (2013) noted that calves fed with diets containing garlic depressed the level of GPT in comparison with those animals fed with control ration.

The present results of kidney function were in agreement with those obtained by Omer et al. (2015) who noted that inclusion of LOG in rabbit diets significantly $(P<0.05)$ decreased creatinine; however, rabbits receiving diet containing $2 \%$ LOG significantly $(P<0.05)$ decreased alkaline phosphatase compared to the control group and rabbits that received $0.5 \%$ or $1 \%$ LOG. 


\section{Conclusion}

Under the same condition, it can be mentioned that adding natural bioactive mixture composed of the juice of lemon, onion, and garlic (LOG) at portions 1.00, 1.00, and $0.125 / 1$ clean water, respectively, to laying hens' diets can be safely used in improving the general health, egg weight, and feed conversion of hens with decreasing blood cholesterol.

\section{Abbreviations}

A:G ratio: Albumin to globulin ratio; AOAC: Official Methods of Analysis; CF: Crude fiber; CP: Crude protein; D1: Control; D2: 1\% LOG; D3: 2\% LOG; D4: 3\% LOG; DM: Dry matter; EE: Ether extract; EN: Egg number; EW: Egg weight; FCR: Feed conversion ratios; Fl: Feed intake; GOT: Glutamic oxaloacetic transaminase; GPT: Glutamic pyruvic transaminase; H: Height of the albumen; HDL: High-density lipoprotein; HU: Haugh unit; LDL: Low -density lipoprotein; LOG: Juice of lemon, onion, and garlic; NFE: Nitrogen -free extract; NRC: National Research Council; OM: Organic matter; SBM: Soybean meal; SEM: Standard error of mean; SPSS: Statistical Package for Social Sciences; W: Weight of the egg; WHO: World Health Organization; YC: Yellow corn

\section{Acknowledgements}

Our deep thanks for Research and Production Station, National Research Centre for saving facilities that make this work possible.

\section{Authors' contributions}

HAAO contributed in plane of work, field work, chemical analysis, arrangement of data, writing and correcting the MS, and helping in the publication. GMHEM contributed in determining egg quality, data calculations, and statistical analyses. SSAM contributed in plane of work, field work, revision of MS, and following publication with the journal (corresponding author). NIB contributed in preparing the bioactive mixture that composes of lemon, onion, and garlic juice (LOG) that was used in this study. SMA contributed in plane of work, field work, revision of MS, and helping in the publication. AKAE contributed in following up the laying hens throughout the experimental period. All authors read and approved the final manuscript.

\section{Funding}

All authors equally shared in financing the cost of the research paper.

\section{Availability of data and materials}

Not applicable for this section.

\section{Ethics approval and consent to participate}

Not applicable for this section.

\section{Consent for publication}

Not applicable for this section.

\section{Competing interests}

The authors declare that they have no competing interests.

\begin{abstract}
Author details
${ }^{1}$ Animal Production Department, National Research Centre, 33 El-Bohouth Street, Dokki, P.O: 12622, Giza, Cairo, Egypt. ${ }^{2}$ Regional Centre for Food and Feed, Agriculture Research Centre, Ministry of Agriculture, Cairo, Egypt.
\end{abstract}

Received: 9 January 2019 Accepted: 10 July 2019

Published online: 22 August 2019

\section{References}

Abo El-Nor SAH, Khattab HM, Al-Alamy HA, Salem FA, Abdou MM (2007) Effect of some medicinal plants seeds in the rations on the productive performance of lactating buffaloes. Int J Dairy Sci 2:348-355

Adibmoradi M, Navidshad B, Seifdavati J, Royan M (2006) Effect of dietary garlic meal on histological structure of small intestine in broiler chickens. J Poult Sci 43:378-383
Agarwal KC (1996) Therapeutic actions of garlic constituents. Med Res Rev 16:111-124

Ahmed AA, Bassuony NI, Awad SE-HS, Aiad AM, Mohamed SA (2009) Adding natural juice of vegetables and fruitage to ruminant diets (B). Nutrients utilization, microbial safety and immunity, effect of diets supplemented with lemon, onion and garlic juice fed to growing buffalo calves. World J Agr Sci 5(4):456-465

Aiad AM, Bassuony NI, Afifi AA, Abo-Donia FM (2008) Adding natural juice of vegetables and fruitage to ruminant diets: (a). Lemon, onion and garlic juice supplemented to diets fed to suckling buffalo calves and its effect on digestibility, growth performance and fungi count. World J Agr Sci 4(2):149-156

Ali M, Thomson M, Afzal M (2000) Garlic and onions: their effect on eicosanoid metabolism and its clinical relevance. Prostaglandins Leukot Essent Fatty Acids (PLEFA) 62(2):55-73

al-Khatib AS (1988) Chihabi's Dictionary of Agricultural and Allied Terminology, English-Arabic: With an Arabic-english Glossary, 3rd edn. Librairie du Liban. https://books.google.com.eg/books/about/Chihabi_s_dictionary_of_ agricultural_and.html?id=hfRNxgEACAAJ\&redir_esc $=y$

Allain CC, Chan PCS, Richmond W, Fu PC (1974) Enzymatic determination of total serum cholesterol. Clin Chem 20:470-475

Amagase H, Petesch BL, Matsuura H, Kasuga S, Itakura Y (2001) Intake of garlic and its bioactive components. J Nutr 131(S3):955S-962S

Anderson KE, Tharrington JB, Curtis PA, Jones FT (2004) Shell characteristics of eggs from historic strains of single comb white Leghorn chickens and the relationship of egg shape to shell strength. Int J Poult Sci 3:17-19

Ankri S, Mirelman D (1999) Antimicrobial properties of allicin from garlic. Microb Infect 1:125-129

Ao X, Yoo JS, Lee JH, Jang HD, Wang JP, Zhou TX, Kim IH (2010) Effects of fermented garlic powder on production performance, egg quality, blood profiles and fatty acids composition of egg yolk in laying hens. Asian Aust J Anim Sci 6:786-791

AOAC (2005) Official methods of analysis, 18th edn. Association of Official Analytical Chemists, Washington, DC

Armstrong WD, Carr CW (1964) Physiological chemistry: laboratory directions, vol 3. Buger Puplishing Co, Minneapolis, p 75

Asrat M, Zeryehun T, Amha N, Urge M (2018) Effects of supplementation of different levels of garlic (Allium sativum) on egg production, egg quality and hatchability of White Leghorn chicken. Livest Res Rural Dev 30(3) http:// www.Irrd.org//rrd30/3/tesf30037.html

Assmann G (1979) HDL-cholesterol precipitant. In: Internist, vol 20. Randox Labs. Ltd. Crumlin Co., Antrim, N. Ireland, pp 559-567

Azeke M, Ekpo KE (2009) Egg yolk cholesterol lowering effects of garlic and tea. J Med Plants Res 3:1113-1117

Banerjee SK, Maulik SK (2002) Effect of garlic on cardiovascular disorders: a review. Nutr J 1(4):1-14

Barragry TB, Powers T (1994) Veterinary drug therapy. Lea and Febiger, Philadelphia

Beliefield A, Goldberg DM (1971) Estimation of serum alkaline phosphates. Enzyme 12:561

Bush BM (1991) Interpretation of laboratory results for animal clinical. Oxford Blackwen Scientific Publications, London, pp 225-299

CAFA (1997) Commission on antimicrobial feed additives. Antimicrobial feed additives. Swedish Official Government Reports 1997. Ministry of Agriculture, Stockholm, p 132

Canogullari S, Baylan M, Erdogan Z, Duzguner V, Kucukgul A (2010) The effects of dietary garlic powder on performance, egg yolk and serum cholesterol concentrations in laying quails. Czech J Anim Sci 55:286-293

Cavallito CJ, Bailey JH (1944) Allicin, the antibacterial principle of Allium sativum. I. Isolation, physical properties and antibacterial action. J Am Chem Soc 66:1950-1951

Chang KJ, Cheong SH (2008) Volatile organosulfur and nutrient compounds from garlic by cultivating areas and processing methods. Fed Am Soc Exp Bio J 22:1108-1112

Chevallier A (1996) Encyclopedia of medicinal plants. DK Publishing, New York, p 81

Chowdhury SR, Chowdhury SD, Smith TK (2002) Effects of dietary garlic on cholesterol metabolism in laying hens. Poult Sci 81:1856-1862

Demir E, Sarica S, Ozcan MA, Suicmez M (2003) The use of natural feed additives as alternatives for an antibiotic growth promoter in broiler diet. Br Poult Sci 44(1):544-545

Doumas B, Watson T, Biggs TWA (1971) Albumin standards and measurement of serum with bromocresol green. Clin Chem Acta 31:87 
Doyon G, Bernier-Cardou M, Hamilton RMG, Eastaigns F, Ramdald CT (1986) Egg quality 2: albumen quality of egg from five commercial strains of white Leghorn hens during one year of lay. Poult Sci 65:63-66

Duncan DB (1955) Multiple rang and multiple F-test. Biometrics 11:1-42

El-Ashry MA, El-Bordeny NE, Khattab HM, El-Sayed HM (2006) Effect of diet supplemented with medicinal herbs on nutrient digestibility and some blood metabolites of buffalo calves. Egypt J Nutr Feed 2:179-191

Elgyyar M, Draughon FA, Golden D, Mout JR (2001) Antimicrobial activity of essential oils from plants against selected pathogenic and saprophytic microorganisms. J Food Prot 64(7):1019-1024

El-katcha MI, Soltan MA, Sharaf MM, Hasen A (2016) Growth performance, immune response, blood serum parameters, nutrient digestibility and carcass traits of broiler chicken as affected by dietary supplementation of garlic extract (allicin). Alex J Vet Sci 49(2):50-54

Fisher K, Phillips CA (2006) The effect of lemon, orange and bergamot essential oils and their components on the survival of Campylobacter jejuni, Escherichia coli O157, Listeria monocytogenes, Bacillus cereus and Staphylococcus aureus in vitro and in food systems. J Appl Microbiol 101(6):1232-1240

Ghasemi R, Zarei M, Torki M (2010) Adding medicinal herbs including garlic (Allium sativum) and thyme (Thymus vulgaris) to diet of laying hens and evaluating productive performance and egg quality characteristics. Am J Anim Vet Sci 5:151-154

Günlü A, Kirikçi K, Çetin O, Garip M (2003) Some external and internal quality characteristics of partridge (A. graeca) eggs. Food Agric Environ 1:197-199

Harold V (1975) Colorimetric determination of glutamate pyruvate and oxaloacetic transaminase, Practical Clin. Biochem. 4th Edn. p. 294

Hassan EH, Abdel-Raheem SM (2013) Response of growing buffalo calves to dietary supplementation of caraway and garlic as natural additives. World Appl Sci J 22(3):408-414

Horie T, Awazu S, Itakura Y, Fuwa T (1992) Identified diallyl polysulfides from an aged garlic extract which protects the membranes from lipid peroxidation. Planta Med 58:468-469

Husdan H (1968) Chemical determination of creatinine with deproteinization. Clin Chem 14:222

Ibrahim MR, El-Banna HM, Omara II, Suliman Marwa A (2011) Evaluation of nutritive value of some citrus pulp as feedstuffs in rabbit diets. Pak J Nutr 10(7):667-674

Khan QSH, Hassan S, Sardar R, Anjum MA (2008) Effects of dietary garlic on cholesterol concentration in native Desi laying hens. Am J Food Technol 3:207-2013

Khan RU, Nikousefat Z, Tufarelli V, NAZ S, Javdani M, Laudadio V (2012) Garlic (Allium sativum) supplementation in poultry diets: effect on production and physiology. World Poult Sci J 68:417-424

Khan SH, Sardar R, Anjum MA (2007) Effects of dietary garlic on performance and serum and egg cholesterol concentration in laying hens. Asian Aust J Anim Sci 21:22-27

Khir AA, Ibrahim Nany S (2007) Effect of coriander and anise as feed additives on performance of buffalo calves. Egypt J Nutr Feeds 10(2):453-460

Kim YJ, Jin SK, Yang HS (2009) Effect of dietary garlic bulb and husk on the physicochemical properties of chicken meat. Poult Sci 88:398-405

Kumar M, Berwal JS (1999) Sensivity of food pathogens to garlic (Allium sativum). Appl Microbiol 84:213-215

Lampe JW (1999) Health effects of vegetables and fruits: assessing mechanisms of action in human experimental studies. Am J Clin Nutr 70:475-490

Lewis W, Elvin-Lewis M (2003) Medical botany plants affecting human health (2nd edition). Wiley, New York

Mahmoud KZ, Saad M, Gharaibeh H, Zakaria A, Amer M (2010) Garlic (Allium sativum) supplementation: influence on egg production, quality and yolk cholesterol level in laying hens. Austr J Anim Sci 23:1503-1509

Manners GD (2007) Citrus limonoids: analysis, bioactivity, and biomedical prospects. J Agric Food Chem 55(21):8285-8294

Marilynn L (2001) Effect of garlic on blood lipids in particles with coronary heart disease. Am J Clin Nutr 34:2100-2103

Melvin JM, Jayochitra J, Vijayapriaya M (2009) Antimicrobial activity of some common spices against certain human pathogens. J Med Plants Res 3: $1134-1136$

Miyake Y, Mochizuki M, Okada M, Hiramitsu M, Morimitsu Y, Osawa T (2007) Isolation of antioxidative phenolic glucosides from lemon juice and their suppressive effect on the expression of blood adhesion molecules. Biosci Biotechnol Biochem 71(8):1911-1919

Miyake Y, Murakami A, Sugiyama Y, Isobe M, Koshimizu K, Ohigashi H (1999) Identification of coumarins from lemon fruit (Citrus Limon) as inhibitors of in vitro tumor promotion and super oxide and nitric oxide generation. J Agric Food Chem 47(8):3151-3157

Motamedi SM, Taklimi SM (2014) Investigating the effect of fenugreek seed powder and garlic powder in the diet on immune response of commercial laying hens' egg. Indian J Sci Res 3(1):277-283

Mottaghitalab M, Taraz Z (2002) Effects of garlic (Allium sativum) on egg yolk and blood serum cholesterol in Aryan breed laying hens. Br Poult Sci 43:S42-\$43

Murray M (1993) The healing power of herbs, vol 143. Prima Publishing Co, Rocklin, p 366

NRC (1994) Nutrient Requirements of Poultry. Ninth Revised Edition. Subcommittee on Poultry Nutrition Committee on Animal Nutrition. Board on Agriculture, National Research Council, National Academy Press, Washington, DC.

Nusairat BM (2007) Dietary supplementation of garlic (Allium sativum): influence on performance parameters, meat quality and humoral immune response in broiler chicks. M.S. Thesis. Jordan University of Science and Technology, Irbid

Oleforuh-Okoleh VU, Harriet M, Solomon N-F, Olorunleke O, Joesph U (2015) Evaluation of growth performance, hematological and serum biochemical response of broiler chickens to aqueous extract of ginger and garlic. J Agric Sci 7(4):167-173

Omer HAA, Ahmed Sawsan M, Bassuony Neamat I, Hewida E-AMH (2015) Response of growing rabbits to diets containing bioactive mixture composed of lemon, onion and garlic juice. Adv Environ Biol 9(24):312-319

Pisani T, Gebski CP, Leary ET (1995) Accurate direct determination of low- density lipoprotein, cholesterol assay. Arch Pathol Lab Med 119:1127

Prasad G, Laxdal VA, Yu M, Raney BL (1995) Antioxidant activity of allicin, an active principle in garlic. Mol Cell Biochem 148:183-189

Prior RL (2003) Fruit and vegetables in the prevention of cellular oxidative damage. Am J Clin Nutr 78:570S-578S

Qureshi AA, Abuirmeileh N, Din ZZ, Elson CE, Burger WC (1983a) Inhibition of cholesterol and fatty acid biosynthesis in liver enzymes and chicken. Hepatocytes by polar fractions of garlic. Lipids 18:343-348

Qureshi AA, Din ZZ, Abuirmeileh N, Burger WC, Ahmad Y, Elson CE (1983b) Suppression of avian hepatic lipid metabolism by solvent extracts of garlic: impact on serum lipids. J Nutr 113:1746-1755

Reddy RV, Lightest SF, Maurice DV (1991) Effect of feeding garlic oil on performance and egg yolk cholesterol concentration. Poult Sci 70:2006-2009

Reitman S, Frankel S (1957) Calorimetric method for the determination of serum glutamic oxaloacetic and glutamic pyruvate transaminase. An J Clin Path 28:56

Rivlin RS (2001) Historical perspective on the use of garlic. J Nutr 131(3S):951S-954S

Saffa HM (2007) Effect of dietary garlic or fenugreek on cholesterol metabolism in lying hens. Egypt J Poult Sci 27:1207-1221

Saki AA, Aliarabi H, Siyar SAH, Salari J, Hashemi M (2014) Effect of a phytogenic feed additive on performance, ovarian morphology, serum lipid parameters and egg sensory quality in laying hen. Vet Res Forum 5(4):287-293

Saleem ZM, Al-Delaimy KS (1982) Inhibition of Bacillus aurous by garlic extracts. J Food Prot 45:1007-1009

Sato A, Terao M, Henna Y (1990) Antibacterial action of garlic extract on food poisoning bacteria. J Food Hygiene Soc Japan 31:328-332

Sivam GP (2001) Protection against Helicobacter pylori and other bacterial infections by garlic. J Nutr 131(3S):1106S-1108S

SPSS (2008) Statistical package for Social Sciences, Statistics for Windows, Version 17.0. Released 2008. SPSS Inc, Chicago

Tietz NW (1986) A method for the rapid determination of albumin of blood plasma. P.589 in textbook of clinical chemistry. W.B. Saunders Company, Philadelphia

Wagr A, Quaratulain S, Altaf H, Ahmad GM, Ashhar Z (1994) Evaluation of different garlic extracts for antibacterial activity. Sci Intl 5:385-386

Wangensteen H, Sanulsen AB, Malterud KE (2004) Antioxidant activity in extracts from coriander. Food Chem 88:293-297

Williams CA, Lamprecht ED (2008) Some commonly fed herbs and other functional foods in equine nutrition: a review. Vet J 178(1):21-31

Witt I, Trendelenburg C (1982) A method for the rapid determination of total protein plasma. J Clin Biochem 20:235

Yalcin S, Onbasilar EE, Reisli Z, Yalcin S (2006) Effects of garlic powder on the performance, egg traits and blood parameters of laying hens. J Sci Food Agric 86:1336-1339

\section{Publisher's Note}

Springer Nature remains neutral with regard to jurisdictional claims in published maps and institutional affiliations. 